\title{
Multinationals Make the Most of IT
}

\section{Silvio Contessi}

$\mathrm{T}$ he U.S. dollar has depreciated by more than 26 percent in trade-weighted terms since its peak in 2002. The lower relative prices paid by foreigners for U.S. goods and services are expanding exports and helping reduce the current account deficit. At the same time, however, there is concern over a potential "firesale" of U.S. firms-i.e., a case in which U.S. firms become so cheap that foreign investors trigger a new wave of international takeovers.

Although economic theory has no clear-cut way to forecast the welfare effects of international changes of ownership or entry of new foreign firms, empirical research can shed light on how multinational corporations have contributed to aggregate productivity. And wages-as discussed previously in this publication ${ }^{1}$ - tend to track productivity. Thus, understanding how multinationals affect productivity growth can help to evaluate the impact of foreign acquisitions on the U.S. economy.

U.S. labor productivity (output per hour) has increased at an average annual rate of 1.84 percent between 1977 and 2006-faster than most countries, at least since 1995. To help find the source of this impressive productivity, we can separate U.S. gross domestic product and productivity growth into that produced by exclusively domestic firms and that produced by multinational firms (i.e., foreign firms with U.S. production units and U.S. firms with foreign production units). The results of a recent study ${ }^{2}$ show that private multinational nonfarm, nonfinancial firms contribute only 40 percent of the output of nonfinancial corporations but more than 75 percent of the increase in labor productivity between 1977 and 2000. Moreover, all of this new productivity in nonfinancial corporate sectors in the late 1990s can be traced back to multinationals.

How have such large productivity gains been possible? Various studies suggest that the productivity advantage of multinationals is caused by technological and organizational advantages that are specific to these firms, rather than to the country in which they operate. Although similar technologies are available at approximately the same prices to both multinational and non-multinational firms, the man- agement structure of multinationals allows them to use new technologies more efficiently, particularly information technologies (IT). The largest productivity advantages are recorded in sectors that make substantial use of IT, such as retail and wholesale, and sectors with superior people management. As the authors of one of these studies put it: "It ain't what you do...but the way you do IT." 3

Hence, even though the ownership of some companies may be transferred abroad because of a "firesale" effect, these firms, along with U.S. multinationals, provide an important contribution to U.S. productivity growth and ultimately to the growth of wages, particularly in IT-intensive sectors.

${ }^{1}$ See http://research.stlouisfed.org/publications/net/20070301/cover.pdf.

2 Corrado, C.; Lengermann, P. and Slifman, L. “The Contribution of MNC's to U.S. Productivity Growth, 1977-2000," in M. Reinsdorf and M. Slaughter, eds., International Flows and Invisibles: Trade in Services and Intangibles in the Era of Globalization. Chicago: University of Chicago Press, 2008 (forthcoming).

${ }^{3}$ Bloom, Nicholas; Sadun, Raffaella and Van Reenen, John. "Americans Do I.T. Better: US Multinationals and the Productivity Miracle." NBER Working Paper No. 13085, National Bureau of Economic Research, 2007.

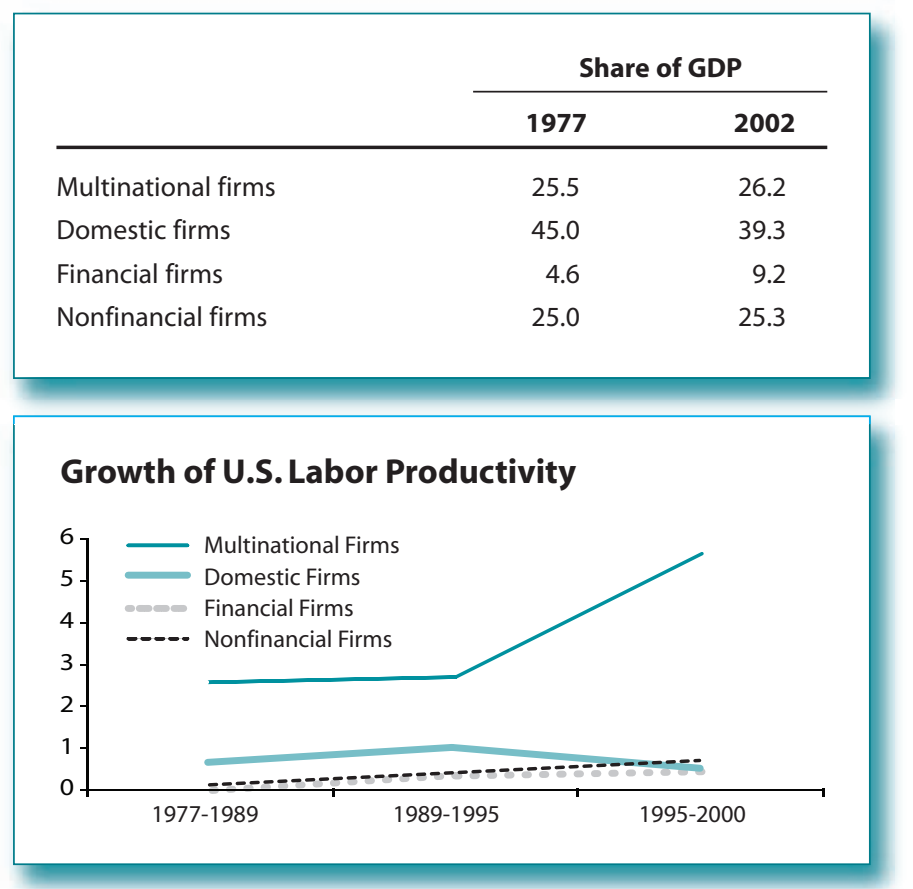

